\title{
The teacher's questioning strategies and the students' responses in the classroom interactions at the first year of SMAN 2 Bandarlampung
}

\author{
Uswatun Hasanah $^{1^{*}}$, M. Sukirlan ${ }^{2}$, Mahpul $^{3}$ \\ FKIP Universitas Lampung, Jl. Prof. Dr. SoemantriBrojonegoro No.1, Bandar Lampung ${ }^{1,2,3}$ \\ ${ }^{1}$ Corespondence: uswatunsan12@gmail.com,
}

\begin{abstract}
The current research was conducted to investigate: (1) the questioning strategies used by the teacher in classroom interaction, (2) the students' responses of the questioning strategies in classroom interaction. The subjects of the study were an English teacher and 30 first year senior high school students at Bandar Lampung. This study was conducted qualitatively by using case study method. The data were collected through classroom observation and interview with students. The observation was used to collect the data of the teacher's questioning strategies. The interview was conducted to elicit the students' responses of the teacher's question. The results showed that the teacher used five teacher's questioning strategies in the classroom interactions, i.e., repetition, decomposition, rephrasing, code-switching, and waittime. Wait time strategies were the most frequently used by the teacher. The students were found to have responded the teacher's questions in forms of both relevant $(77 \%)$ and irrelevant (23\%). This suggests that the teacher's questions were effectively addressed by the majority of the students.
\end{abstract}

Keywords: classroom interaction, teacher's questioning strategies, students' responses.

\section{INTRODUCTION}

Asking a question to the students does not always work in some cases regardless of the repertoire of questions that can be applied by the teacher in the classroom. Teacher, sometimes, fails to encourage the students to speak more by answering the questions due to certain circumstances, such as the question that is not understood by the students or the length of the question that is too long. For that reason, it is important to not only look at the type of the questions but also the questioning strategies employed by the teacher since developing a repertoire of questioning strategies is also one of the best ways for teacher to establish and sustain the interactive classroom interaction. Questioning strategies may also provide necessary stepping stones for the students to communicate (Brown, 2001).

There are many types of questioning strategies that can be applied by the teacher. However, from so many types of questioning strategies applied by a teacher, this study will only be based on typical questioning strategies proposed by Chaudron (1988), Chaudron and Wu (1993) and Anwar (2000) frameworks. According to the aforementioned frameworks, repetition, rephrasing, decomposition, code switching, and wait-time are the most common strategies used by the teacher to get the desired answer or responses from the students.

Students in Indonesia are still shy in participating during teaching and learning process. In addition, Husnaini (2005) and Stianingrum's (2010, as cited in (Hadiani, 2014)) findings in their 
studies show the percentage of teacher talk is more than 60\%. The percentage shows that teacher mostly dominate the interaction in the classroom. Meanwhile, the students are rarely active and participative in the whole classroom interaction. Teacher's domination of classroom interaction can discourage the students to participate and speak more in the target language. The students may get exposure to the target language by listening to the teacher's talk dominating the interaction, but on the other hand, the students get less experience to use and to apply the exposure they get from the teacher.

Some related studies about questioning strategies were conducted by researchers. First, Yu (2010) found that in teaching practice and instruction in the classroom the question strategies mostly used repetition, code switching and pauses. Second, Haliani (2013)found that there were five teacher's questioning strategies that were used in the classroom observation. There were repetition, simplification, blank-filling, code switching, and wait-time. Third, Sari (2011) found that the teacher employed some questioning strategies namely blank filling, repetition, rephrasing, simplification, exemplification, code-switching, and wait time. The most strategy used by the teacher is blank filling. The last researcher, Hadiani(2014) in her research found that the most dominant questioning strategy employed by the teacher was rephrasing strategy since this strategy was effective in eliciting the students' responses in the classroom interaction.

The researcher has conducted a pre observation research to find a problem from SMAN 2 Bandar Lampung, she found that the students were quite able to communicate in English during the teaching learning process, yet the students are not too active in teaching and learning process. Thus, the researcher is interested in analyzing the classroom activity at that school. More specific,this study is aimed to investigate the questioning strategies used by the teacher in classroom interaction and also the students' responses of the questioning strategies in classroom interaction.

\section{METHODS}

This study employed qualitative approach. As cited in Creswell(2007), qualitative approach is an approach to inquiry that begins with assumption, world view, possibly a theoretical lens, and the study of research problems exploring the meaning individuals or groups describe to a social or human problem. The design of the research is a case study. As cited in L.R Gay and Millis(2009), case study is a qualitative approach in which the focus of the study isknown as a bounded system (e.g. individual teachers, a classroom, or a school). This study attempted to investigate teacher's questioning strategies that arein classroom interaction. It also explored the students' responsetoward the teacher questioning strategies used by the teacher in theclassroominteraction, considering the aims of this study, case studyappropriate to be used, since it focused on the process of classroom interaction innatural setting.

The participant of this study was an English teacher and his learners in X IPS 3 class. The object of the data is the interaction between the teacher and 30 first year studentsin English lesson class at SMAN 2 Bandar Lampung. In this research, the teacher's questions and the students' responses are observe and record by the writer in 90 minutes. The data were collected through classroom observation and interview with students. The observation was used to collect the data of the teacher's questioning strategies. The interview was conducted to elicit the students' 
responses of the teacher's question.After collecting all the data from classroom observations and videotaping,the data were analyzed based some steps adapted from Suherdi (2009). In the last step, the researcher attempted to answer the researchquestions which had been presented.

\section{RESULTS AND DISCUSSIONS}

For the research was conducted in order to answer the research questions, the researcher has done 4 observations in a class, and she found the data as follows:

\section{The most questioning strategies used by the teacher}

Based on the results of data analysis, there were five questioning strategies used by the teacher. They were repetition, rephrasing, code-switching, decomposition, and wait-time. Wait-time is defined as the amount of time a teacher pauses after delivering questions or prior to addressing further question to either the same learners or others. Repetition is a repeated question which is posted by the teacher in verbal response from their students. Rephrasing is used by posting the questions in another way to make it more understandable. In addition, rephrasing can be done by providing alternative or "choice" questions.Decomposition is a technique which refers to breaking down the initial question into several questions which are more simple and shorter . Code switching is addressed to encounter learners' limitation in teacher's understanding and to control teacher's confusion of appropriate English word for her utterance. In code switching technique, the language use was mixed without changing the topic that is discussed.The questioning strategies appeared in the classroom observation and video-taping. The researcher has observed X IPS 3 class 4 times. The distribution of the teacher's questioning strategies for all the observations is presented in the following table.

Table 3.1 Teacher questioning strategies

\begin{tabular}{lllllll}
\hline $\begin{array}{l}\text { Teacher's } \\
\text { questioning } \\
\text { strategies }\end{array}$ & $\begin{array}{l}1^{\text {st }} \\
\text { meeting }\end{array}$ & $\begin{array}{l}2^{\text {nd }} \\
\text { meeting }\end{array}$ & $\begin{array}{l}3^{\text {th }} \\
\text { meeting }\end{array}$ & $\begin{array}{l}4^{\text {th }} \\
\text { meeting }\end{array}$ & TOTAL & Percentage \\
\hline Repetition & 2 & 4 & 2 & 3 & 11 & $9 \%$ \\
\hline Decomposition & 2 & 5 & 15 & 3 & 25 & $20 \%$ \\
\hline Rephrasing & 1 & 3 & 3 & 6 & 13 & $10 \%$ \\
\hline Code-Switching & 8 & 8 & 6 & 4 & 26 & $21 \%$ \\
\hline Wait- time & 15 & 8 & 14 & 14 & 51 & $40 \%$ \\
\hline Total & 28 & 28 & 40 & 30 & 126 & $100 \%$ \\
\hline
\end{tabular}

Table 3.1 shows that wait time strategies were the most frequently used by the teacher.The gap between the three strategies that usually used by the teacher was not significant.The total of questioning strategies used by the teacher was 126 strategies. Table 3.1 also shows that teacher questioning strategies used by the teacher includes11 repetition (9\%), 25 decomposition (20\%), 13 rephrasing (10\%), 26 code switching (21\%) and 51 wait time (40\%).

In the previous study, Chaudron (1988) reveals his study about teacher's questioning strategy. He states that one of the effective teacher's questioning strategies is wait-time. The amount of time that a teacher gives students to think of the answer and raise their hands is called wait time, 
and research published in the early 1970s and mid-1990s is still used to show that it is a critical instructional tool. While wait time may be an uncomfortable strategy for teachers and students at first, it does get easier with practice. Teachers will notice a better quality and/or an increase in the length of responses as students have the time to think of their answer before raising their hands. Student-to-student interactions may also increase as they become better able in formulating their answers. That pauses of a few seconds - whether it's called wait time or thinks time - can make a dramatic improvement in learning.

This findings is in line with Haliani (2014)'s finding in her research entitled teacher's questioning in classroom interaction and students' responses in young learners. She used a qualitative method in her research and observed the teaching and learning activity. In her research, she found thatthere were five teacher's question strategies that were used in the classroom observation. They were repetition, simplification, blank-filling, code switching, and wait time.

Based on analyzed data, in the first meeting, the learning material was about advertisement. In that meeting teacher focused on discussion. First of all, the activity was greeting, and then the teacher tried to display a video as example of advertisement, but the light out, so the teacher divided students into several groups and then asked students to find the information about advertisement from internet using their self phone. The information inculedes the purpose, content, language features, and also the example. After that the students were assigned to make a report about their discussion. The pattern of this meeting was greetings, group discussion, and then make a report about the discussion. The strategies that were mostly used by the teacher at the first meeting were wait time and code switching. Wait time appeared 15 times while code switching 8 times.

In the second observation, the learning material was still about advertisement, it was just more specific, which is about brochure. The pattern at the second observation was the same as the first observation which is greeting, making a group discussion, and then make a report about the topic has been discussed. The strategies that were mostly used by the teacher in the second observation were the same as the strategies used in the first observation, there were wait time and code switching, which appeared 8 times each

In the third observation, the topic was about recount text. After greeting, the teacher played a video as example of recount text. After that, the teacher ask the student about the information that was found in that video. And then, the teacher invite a voluenteer to have a dialogue with the teacher in front of the class as an example of the assignment that will be done by other students. The next activity was group discussion. In closing that lesson, the teacher asked about the conclusion of material they has been discussed. The strategies that were mostly used by the teacher were decomposition and wait time, which appeared 15 times of decomposition and wait time 14 times. It was interesing to discussed, because the pattern at this meeting was different, where at the begining of the lesson, the teacher provided a video as example and discusses them first. The students have been invited to learn about the topic of the day's through discussion based on the examples shown. Beside of that, students are also trained to deeper their understanding of the material by giving the example about what will they to do by inviting one of the students as a volunteer. The teacher mostly used decomposition strategy in orded to elicit 
the students' verbal responses. They make different questions based on the initial ones. It could provide enough chances for students to give their own opinions or arguments. Furthermore, there were many students who tried to give responses. It way easy for the teachers to elicit more responses from the students. Many students raises hand and tried to answer when the teachers decomposed the question into some simple question related to the initial question. Although, not all of the answers are relevant. Furthermore, the classroom observation shows that decomposed question succeeded in making the students more active in the discussion. Another function of the decomposition strategy used by the teacher was that it could lead to the conclusion of the lesson.

In the last observation, the learning material was about report text. The main activity in that meeting was presentation. The classes were dominated by the students for they had to present theirtask about report text.

Based on the result, wait time strategy was mostly used in each meeting. Because, based on the observations and statements from the teacher, most of the students were lack of vocabulary. Students in the first year have limited vocabulary. Students still difficult to comprehend what the teacher said. When the teacher asks a question, students cannot immediately answer it because students need time to understand the meaning of the question. Then, based on the results of interviews with students, students agreed that they need time to understand the questions posed by the teacher. In conclusion, students do not answer the teacher's questions because students do not understand the teacher's questions, and student's lack of vocabulary.

\section{The Students' Responses of Questioning Strategies Used the Teacher}

There

are

twoimportantwaystorespondtheteacher'squestioningstrategybasedonSuherdi'sframework (2009), namelyrelevantresponse (Rr)andirrelevantresponse (Irr).The distribution of the students' responses for all the observations is presented in the following table.

Table 3.2 Student Distribution Frequency

\begin{tabular}{|c|c|c|c|c|c|c|c|c|c|}
\hline \multirow[t]{2}{*}{$\begin{array}{l}\text { Questioning } \\
\text { strategies }\end{array}$} & \multicolumn{2}{|c|}{$\begin{array}{l}\text { First } \\
\text { meeting }\end{array}$} & \multicolumn{2}{|c|}{$\begin{array}{l}\text { Second } \\
\text { meeting }\end{array}$} & \multicolumn{2}{|c|}{$\begin{array}{l}\text { Third } \\
\text { meeting }\end{array}$} & \multicolumn{2}{|c|}{$\begin{array}{l}\text { Fourth } \\
\text { meeting }\end{array}$} & \multirow[t]{2}{*}{ total } \\
\hline & $\mathrm{Rr}$ & Irr & $\mathrm{Rr}$ & Irr & $\mathrm{Rr}$ & Irr & $\mathrm{Rr}$ & Irr & \\
\hline Repetition & 2 & - & 3 & 1 & 2 & - & 3 & - & 11 \\
\hline Decomposition & 1 & 1 & 4 & 1 & 11 & 4 & 3 & - & 25 \\
\hline Rephrasing & 1 & - & 3 & - & 3 & - & 4 & 2 & 13 \\
\hline $\begin{array}{l}\text { Code- } \\
\text { switching }\end{array}$ & 7 & 1 & 6 & 2 & 5 & 1 & 3 & 1 & 26 \\
\hline Wait time & 12 & 3 & 5 & 3 & 10 & 14 & 9 & 5 & 51 \\
\hline
\end{tabular}




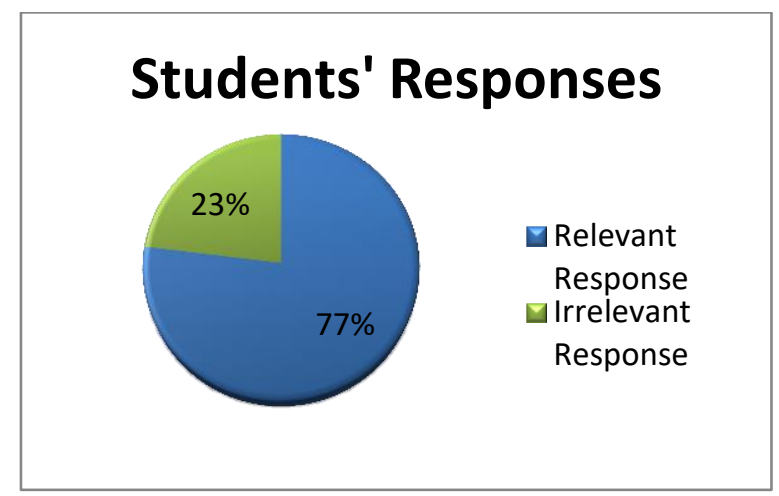

Figure 1. Student Distribution Frequency

Table 3.2 and figure 1 show about the students' responses toward the teacher's questioningstrategies. The students were found to have responded the teacher's questions in forms of both relevant (77\%) and irrelevant (23\%). Therefore, the use of teacher's questioning strategies mayproduce higher relevant responses than irrelevant responses in this study. When the teacher used wait time strategy, it resulted in 36 relevant responses and 15 irrelevant responses.

When the teacher used repetition strategy, it gets 22 relevantresponses and 5 irrelevant responses. 21 relevant responses and 5 irrelevant responses when used code switching strategy. Then, there were 19 relevant responses and 6 irrelevant responses when used decomposition strategy. When teacher used rephrasing strategy, it gets 11 relevant responses and 2 irrelevant responses. And then, there were 10 relevant responses and 1 irrelevant response when the teacher used repetition strategy.

The researcher has interviewed 9 students who are divided into 3 groups based on student participation in the learning process. The group divided into 3 level participation students; Lowlevel participation, middle-level participation, and high-level participation students.

Based on the research, if complex questions were used, the students often respond relevantly. Therefore, the teacher mostly used questioning strategies which not function to probe or ask deeper thinking from students.According to the observation, the students were lack of speaking practice, and they were not accustomed to use English more often. Another problem was that students' limited vocabulary attainment. This resulted in the difficulty for them to respond relevantly.

Based on interviewed data, wait time strategies help students deliver relevant responses. According to students, students need time to digest the language and understand what the teacher's question means. The teachers should gave a little time to think for the students whose names were called. The students needed to take their guts to produce loud and clear answer.Meanwhile, from the findings, it can be seen that the teacher used different questioning strategies in encouraging the students to actively participate. This indicates that the teacher has many variations in modifying questions to be students in an attempt to elicit students' responses. 
Based on the findings, it can be seen that the teacher used different questioning strategies in encouraging the students to actively participate. This indicates that the teacher has many variations in modifying questions to be students in an attempt to elicit students' responses.

According to the result of analysis, questioning strategies applied by the teacher really helped the students to comprehend teacher's question as the students could answer $77 \%$ of teacher's question after the question were modified by using the questioning strategies. In addition, all of the students interviewed also stated that questioning strategies are helpful in helping them to comprehend the question given by the teacher.

Another finding indicates that the teacher tended to ask students to respond in short answer, such as about the examples, facts, things. This is a display question type (kayaoglu,2013 as cited in (Fitriati, Israfa, \& Trisanti, 2017)). A display question refers to a question which the teacher already know the answer. The purpose is " to make the students display some previouslylearned knowledge" (Wu,1993). This finding is in line with the study conducted by James and Carter (2006, as cited in (Fitriati, Israfa, \& Trisanti, 2017)) that commonly students in a school actually tend to respond more often through short and literal level of question.

In this study the teacher gave questions to the students for certain purpose; one of the purpose was to encourage students to speaking English. Yet, students responses could not be obtained easily. This made the teacher aware that she has to change the ways she delivered the questions. Moreover, many students have different characteristics. There were fast, slow learner, high, middle, low achievers in the classes. Consequently, some students were silent and others were active in responding to the teachers' question. Not all of them could respond quickly; they needed to be stimulated and given time to think as well.

The teacher also often used the Indonesian language in her questioning. The use of Indonesian was absolutely easy to understand, but the students could not develop their English skills weel. Apparently, the teacher sometimes needed to translate her questions into indonesian to be quikly answered by the students.

In conclusion, the students' responses could be affected by the teacher's questioning strategies applied in the classroom interaction. It is proved by the total of relevant responses that were higher than irrelevant responses. It showed that the teacher has applied questioning strategies in young learners classroom interaction effectively. However, the percentage of irrelevant responses left important note, that some questioning strategies did not give effective contribution in the classroom interaction. This suggests that the teacher's questions were effectively addressed by the majority of the students.

\section{CONCLUSIONS AND SUGGESTIONS}

The results showed that the teacher used five teacher's questioning strategies in the classroom interactions, i.e., repetition, decomposition, rephrasing, code-switching, and wait-time. Wait time strategies were the most frequently used by the teacher. The students were found to have responded the teacher's questions in forms of both relevant (77\%) and irrelevant $(23 \%)$. This suggests that the teacher's questions were effectively addressed by the majority of the students. 
Furthermore, the author found some things that need to be considered. For English teachers, they should applysome questioning strategies when delivering questions in order to elicit students' responses, especiallytogetrelevantresponsesfromthestudents.Itisreallyimportanttodo, becauseitiscansupportthestudents' learningprocess.

Additionally, for the future researchers who are willing to explore the topic of questioning strategies. It is suggested that other writers can focus the study on the most strategies frequently appeared in the EFL classroom. Besides, they can involve the eleventh or the twelfth grader teachers as the participant. Moreover, forthe future researchers can take bilingual or international standard school as the site of the study. In collecting the data, future researcher can use questionnaire and document analysis, besides interview and video recording.

\section{REFERENCES}

Anwar, Z. (2000). Interactional features as implemented in teaching English at Madrasah Aliyah Negeri (MAN) 4 Jakarta. Bandung: Universitas Pendidikan Indonesia.

Brown, H. D. (2001). Teaching by principles: An interactive approach to language pedagogy. New York: Addison Wesley Longman, Inc.

Chaudron, C. (1988). Second language classroom (research on teaching and learning). Melbourne: Cambridge University Press.

Creswell, J. W. (2007). Qualitative inquiry and research design: choosing among five approaches. 2nd Ed. California: Sage.

Fitriati, S. W., Israfa, G. A., \& Trisanti, N. (2017). Teachers' questioning strategies to elicit students' verbal responses in EFL classes at a secondary school. English Review: Journal of English Education, 5(2), 217-226.

Gay, L. R., \& Airasian, M. G. (2009). Educational research competencies for analysis and application. 9th Ed. New Jersey: Pearson Educational Limited.

Hadiani, S. N. (2014). Teacher's questioning strategies in classroom interaction. Bandung: Universitas Pendidikan Indonesia.

Haliani, H. (2013). Teacher's questioning strategies and students' responses in young learners' classroom interaction. Bandung: UPI.

Husnaini. (2005). Teacher talk and learner talk in classroom interaction ( An interaction analysis to an English language class at SMPN 29 Bandung). Universitas Pendidikan Indonesia: Unpublished Research Paper.

Sari, Y. (2011). An analysis of teacher's questioning strategies in a public senior high school in Bandung . Universitas Pendidikan Indonesia: Unpublished Research Paper.

Suherdi, D. (2009). Classroom discourse analysis; A systemiotic approach. Bandung: CELTIC Press.

Wu, K. Y. (1993). Classroom interaction and teacher questions. Retrieved December 2016, from RELC Journal, 24(2): 49-68: http://rel.sagepub.com/content/27/2/30.full.pdf+html

$\mathrm{Yu}$, w. (2010). An analysis of college English classroom questioning. Journal of Language Teaching and Research 1 (2), 136-144. 